\title{
Promoting the forgiveness in premarital counseling as a way to get a successful marriage
}

\author{
Adnan Arafani *) \\ University Pendidikan Sultan Idris, Malaysia \\ ${ }^{*}$ Corresponding author, $\equiv$ e-mail: ariagunadharma@yahoo.co.id
}

\begin{abstract}
Forgiveness is capable to create a change in cognitions, emotions, and behaviors toward somebody who committed a hurtful act, it can be a useful tool for counselor to deal with client's problems including marital issues. One of the major issues in marriage is divorce. Meanwhile, the previous studies proved those individuals who experienced premarital counseling gained a high level of marital satisfaction. This article literately reviews how forgiveness can be used as a main topic in premarital counseling as an effort to achieve a successful marriage.
\end{abstract}

Keywords: forgiveness, premarital counseling, successful marriage

How to Cite: Arafani, A. (2017). Promoting the forgiveness in premarital counseling as a way to get successful marriage. Couns-Edu: International Journal of Counseling and Education, 2(1): pp. 1-5. DOI: $10.23916 / 002017025310$

\section{Introduction}

In the early $20^{\text {th }}$ century, researchers predicted there will be a rising trend of marital problems in the society, even in 1999 as many as three out of five marriages in big cities in the western word will be ended in divorce during the first fifteen years of existence (Merwe, 1999). Today, as the word and technology develop continuously and unstoppable, the factor risks of divorce are also become more sophisticated, information technology and social interaction reach the peak and bring both advantages and disadvantages in different ways. In fact, the disadvantage for family live today seems to be very destructive. BKKBN (National Council for Family Welfare of Indonesia) stated officially that Indonesia had reached the highest rate of divorce among Asia Pacific countries (Rahman, 2012) and based on data from Ministry of Religion in 2013, the number of marriage as much as 2.218.130 events in entire of Indonesia while the divorce rate within the same year up to 14.6 percent, or 324527 events (Sasongko, 2014). Furthermore, Indonesia is also ranked as the second fatherless country after the USA, this means that many children in families are leaved by their fathers caused by divorce or separated (Fauzani, 2016).

However, the development of social science is also optimistic toward future social live, in counseling discipline there is a special field that elaborate family-correlated problems, even to prevent the problems, counseling provides premarital counseling (Carroll \& Doherty, 2003). In premarital counseling, individual or couple are not only offered the knowledge to prevent future problems but also trained with skills needed in the marriage live in order to gain successful marriage.

Many researchers had elaborate skills through their experiments and research to find both the effective model and the appropriate intervention in marriage counseling, and some latest literatures have discussed specifically about forgiveness in couple and family context, as work of Worthington and David (2010) 


\section{COUNS-EDU •}

Vol.2, No.1, March 2017

which obviously reviewed, conceptualized, and analyzed that. But, the topic of forgiveness in premarital counseling is considered as a lack of being discussed.

Through the process of reviewing the literature with computer search of a variety of electronic databases in authority access of Tuanku Bainun Library of Sultan Idris Education University, including Psych Info, Emerald Inside, JSTOR, Proquest Social Sciences Index, Taylor \& Francis Online, EBSCOHOST and digital dissertations this work endeavor to describe a probability of use of forgiveness as a main 'weapon' to maintain our family in the society, and this also directs future counselors, especially in Indonesia and Malaysia, to start a step in new setting of counseling namely marital counseling and emphasize that taking advantage of forgiveness in premarital counseling is a bright way to nurturing future family and making a marriage, as an important step of live, become long lasting.

\section{Discussion}

\section{Successful Marriage}

Help the couples to build the strong family should be our attention in order to create health society, it is important to aware that the way someone maintain his relationship in his or her family is likely correlate with the way his or her next generations maintain their relationship. This is called 'relationship history' which is in other word it affects the couple's current relationship, such that couples who had parents that were not divorced and displayed low levels of conflict reported higher levels of relationship satisfaction (Halford et al., 2003).

Following that, the work of Bram (1979) to 608 undergraduate students of Indiana University in assessing what they assume as the strength of family base on their own live discovered that from the side of children these five concepts were perceived to be related to their families' strengths: 1) religious orientation, 2) togetherness, 3) recreational activities, 4) satisfaction with communication pattern with parents, and 5) perceived value placed on strong families by organizations and institutions.

In 1977, Stinnett and Saur studied 157 subjects in 99 families in Oklahoma to examine the relationship patterns among strong families. One of the major findings that emerged was that one of the primary characteristics of strong families is the members' enhancing one another's self-esteem through expression of appreciation and compliments. This study also identified other areas as characteristics of strong family: a willingness to spend time together (participating in activities as a family), good communication patterns, and commitment to a religious life style. Later Stinnett (1979) completed his research by adding the ability to deal with crisis in a positive way as a family strength.

The ability to solve problem in Stinnett study was not detailed, whereas an unsolved problem potentially directs the situation to be worse and even encourages one of couple to start talking about divorce.

\section{Divorce}

Once the couple or one of couple initiates to talk about divorce, it indicates that this marriage and family relationship is in a serious problem, and this marriage is uncounted as successful. Zimmerman and Cervantes (1960) investigated the main characteristic of successful marriage is had not been interrupted by divorce and even separation. So, divorce and separation are critical be understood by anyone who will and in the deal with marriage.

There are some classifications of divorce and its potential to be, as Berne (1961) has grouped into several significant classes. There are those couples who do not get along well together, but do not wish a divorce. Other couples may be experiencing what Berne (1961) calls "an outbreak of script" involving some acting-out behavior or tendency which has been latent throughout the marriage. Another class involves divorced people willing to consider reconciliation. The final class, as described by Berne (1961), involves those couples wishing to justify a divorce by demonstrating "how hard each has tried" in order to proceed with a divorce with "clear conscience". Other couples may be experiencing what Berne (1961) calls "an outbreak of script" involving some acting-out, behavior or tendency which has been latent throughout the marriage. 
On the other side, looking at the therapist perspective, through a survey of some 638 professionals in marriage and family life, Axelson and Glick (1979) asked what major topics were they thought as challenging in their field over the next decade, the topics most listed were: 1) divorce, separation and desertion; 2) variant life styles; 3) child abuse and family violence; 4) marital communication/marital enrichment; 5) age and aging families; 6) single parenting; and 7) both changing sex roles and public policy and the family. Take attention on the first topic, divorce, separation and desertion are confirmed as main topic in the field of practice.

The risks of divorce are, surprisingly, likely tend to occurred in the first four year of marriage, the study of Karney \& Bradbury (1997) discovered this fact through their work in longitudinal assessment to analyze marital satisfaction sought links between marital satisfaction, neuroticism and behavioral issues. They found at the conclusion of the four years period, 32 percent of the marriages had resolved in divorce or separation, with major shifts toward dissolution seen between 18 and 24 months and again between 42 and 48 months (Karney \& Bradbury, 1997). More interestingly, for both spouses and across all categories, Karney and Bradbury also report that mean levels of self-reported marital satisfaction decreased and the variability increased over the first 4 years of marriage.

\section{Premarital counseling (PMC)}

Peterson (1968) has reviewed all the books on the practice of marriage counseling published over a twenty-five years period and concluded that "marriage counseling is a practice without a theory", but now the marriage counseling is growing rapidly both in academics and in practices since there is massive improvement of some field of counseling that was especially in the church setting and was exclusively for Christian and now come up to surface as a more acceptable kind of general counseling for everyone.

$\mathrm{PMC}$ is defined as a specific type of systemic therapy aimed at assisting couples that are considering marriage. Interventions include "understanding and improving the premarital individual and couple interactional factors that can influence both quality and the stability of the marital relationship" (Holman \& Linford, 2001). The focus of premarital counseling (PMC) is to prepare a couple for a lifelong relationship. In general, PMC programs are based on two principles: preventing future problems for couples and providing couples with skills-based training (Carroll, 2003). In Indonesia, premarital counseling is not a common type of counseling service yet, premarital counseling is still counted as individual counseling as the marital problems talked in the individual counseling session, this specific type of counseling is a new profession that would develop in Indonesia (Frischa Meivilona Yendi, 2013), it is likely not congruent with the need of marriage counseling or premarital counseling as the rate of divorces in very high.

Even though, Hudson research confirmed that those individuals who have experienced premarital counseling or premarital counseling including assessment tools self-report higher levels of marital satisfaction as depicted by the analysis of the MSI-R scores for these participants. (Hudson, 2008) while the high level of marriage satisfaction is indicated the little risk of divorce.

\section{Forgiveness}

Jameson K. Hirscha (2012) defined forgiveness as an universal value of human being which every person respect this value, majority of culture and religion all over the world also value this attitude. Forgiveness is conceptualized as a motivationally and volitionally unique method of coping that does not require restitution, retribution or reconciliation, and which can be dispositional and/or situational in nature. Further, forgiveness is described as a process (Jameson K. Hirscha, 2012).

McCullough (2000) stated that While there are important links between forgiveness and reconciliation, they are quite different phenomena. Reconciliation entails the restoration of trust in a relationship that has been damaged. It is a major interpersonal achievement. Both parties must be involved and both must contribute to a resolution. Forgiveness is something that is granted by the person who has been wronged. It can be carried out alone or in interaction with the offender. Forgiveness does not mean that reconciliation could or should occur. For example, a person may choose to forgive a former partner for a betrayal of trust that ended the relationship, but still choose not to reconcile. Yet, even in the absence of reconciliation, forgiveness is a worthwhile goal. 


\section{COUNS-EDU •}

Vol.2, No.1, March 2017

The forgiveness juts require the willingness of victims; it does not require the offender admission. The willingness that is voluntarily undertaken by a victim of an offence, consisting of offering, feeling or seeking a change from negative to positive cognitions, behaviors and affect towards a transgressor, including self, others, and God (Toussaint, 2005).

In his limitation chapter in his dissertation, Hudson (2008) stated:a researcher cannot eliminate the possibility that the most impactful factor of marital satisfaction might be forgiveness. It is possible that individuals are more open to freely forgiving one another for mistakes or offenses and therefore sense higher levels of satisfaction because they don't hold grudges regardless of the response of their mates.

Forgiveness may be initiated by reasoning, simply experiencing positive other-oriented emotions toward the transgressor, acting kindly toward the transgressor, or having the transgressor act contritely or in a way that provokes empathy, sympathy, compassion, or love. (Everett 1. Worthington, 2010). The understanding of forgiveness is very crucial to counselor.

\section{Forgiveness in Premarital Counseling Model}

Interpersonal conflict in family in verbal way easily change into physical abuse as the anger mastering husband and then aim to express the anger in physical violence. In other word, revenge is a causal motive for acts of violence, McCullough, Sandage and Worthington (1997) suggest that forgiveness may be an important variable in dealing with interpersonal conflict, aggression, and violence. Moreover, the quantitative literature has shown that healthy communication among intimate partners is a strong predictor of relationship and marital satisfaction (Gottman, 1994; Gottman, Coan, Carrere, \& Swanson, 1998). Furthermore, healthy communication is defined by one's openness with his/her partner, the ability to discuss particular issues and behaviors that bother him/her, and request changes without criticizing (Nichols, 2007). The communication skills in preparation of marriage is still an odd thing, while the communication in business-oriented purposes become more popular, as there are a little number of training centre where the participants learn about household communication and husband-wife interaction than Public Speaking Learning Centre to avoid divorce and get the successful marriage. This, as opportunity and also as challenge, should be the concern of counselor, specifically the marriage counselor. Forgiveness is considered as a most effective preventive tool to avoid the causes of verbal conflict and therefore automatically cover the possibility of physical abuse and divorce itself. Creating sufficient awareness of forgiving before two people live in together their new family is a field of premarital counseling in which emerged as a way to lower the chances of divorce and also to increase couple satisfaction after marriage.

Premarital programs provide couples with necessary skills to enhance communication, problem solving, and decrease conflict by addressing expectations within marriage (Stutzmen, 2011), so that, the skill of forgiving is seem to be a powerful if the programs are designed well. It should contain concepts and techniques of forgiveness.

To design an effective premarital counseling program by theme of forgiveness and put it into a module model is our academic homework, and later the module should be examined empirically, but once the evidences are supporting this article idea, it could be a solution for the phenomena of increasing trend of divorce in Indonesia.

\section{Conclusions}

The Forgiveness in premarital counseling is as a way to get a successful marriage. Forgiveness is capable to create a change in cognitions, emotions, and behaviors toward somebody who committed a hurtful act; it can be a useful tool for counselor to deal with client's problems including marital issues. The counselor must be have the knowledge and skill about the forgiveness in premarital counseling.

\section{Acknowledgments}

We would like to thank to Associate Professor Dr Muhammad Bazlan bin Mustafa and Dr Hapzah Mohd Yosof for the support and faculty member of Faculty of Education and Human Development 
Universiti Pendidikan Sultan Idris. The earlier version of this article was presented in $4^{\text {th }}$ International Counseling Seminar (ICS) 2016, Padang Indonesia.

\section{References}

Axelson, L. J. (1979). Family Specialists Look Ahead: Their Attitudes, Beliefs, Consensus, and Perceptions of Future Issues. Family Coordinator, 28, 2, 149-155.

Beam, W. W. (1979). College Students' Perceptions of Family Strengths. In N. C. Stinnett, Building Family Strengths. Lincoln: University of Nebraska Press.

Carroll, J. S. (2003). Evaluating the effectiveness of premarital prevention programs: A meta-analytic review of outcome research. Family Relations, 105-118.

Everett 1. Worthington, j. A. (2010). Interventions to promote forgiveness in couple and family context ;. Journal of Psychology and Theology, Vol. 38, No. 4, 231-245.

Fauzani, P. Problem Keluarga - Kemenag Dorong Peningkatan Kualitas Perkawinan. Access 13 January 2017. Retrieved from Koran Jakarta: http://www.koran-jakarta.com/angka-perceraian-terus-meningkat/.

Frischa Meivilona Yendi, Z. A. (2013). Counseling Service for Gilrs in Mariage Age. Jurnal Konseling dan Pendidikan, 109-114.

Halford, W. K. (2003). Best practice in couple relationship education . Journal of Marital and Family Therapy, 385-406.

Holman, T. B. (2001). Assumptions and methods. In T. B. Holman, Premarital prediction of marital quality or breakup (pp. 29-45). New York: Plenum.

Hudson, J. G. (2008). A Study Of Marital Satisfaction: The Efficacy Of Premarital Counseling Programs In Relation To Marital Satisfaction. A Dissertation: Capella University.

Hudson, J. G. (2008). A Study Of Marital Satisfaction: The Efficacy Of Premarital Counseling Programs In Relation To Marital Satisfaction. Capella University: a doctoral research, not published.

Jameson K. Hirscha, J. R. (2012). Forgiveness as a moderator of the association between anger expression and suicidal behaviour. Mental Health, Religion \& Culture, 279-300.

Karney, B. R. (1997). Neuroticism, Marital Interaction, and the. Journal of Personality and Social Psychology, 72(5), 1075-1092.

McCullough, M. E. (1997). To forgive is human: How to put your past in the past. IL: Intervarsity.

McCullough, M. P. (2000). forgiveness: Theory, Research, and Practice. New York: Guild for Press.

Merwe, S. S. (1999). Developing A Premarital Training Course For Prospective Couples As Preparation For Successful Marriage. Ann Arbor: School Of Psychology And World Missions Fuller Theological Seminary.

Nichols, M. P. (2007). The essentials of family therapy. Boston: Pearson Education.

Peterson, J. A. (1968). Marriage and Family Counseling: Perspective and Prospect. New York: Association Press.

Rahman, Y. (2017, February 15). Perceraian di Indonesia Rekor Tertinggi se-Asia Pasifik. Retrieved from Berita Satu:http://www.beritasatu.com/keluarga/31699-perceraian-di-indonesia-rekor-tertinggi-se-asiapasifik.html.

Sasongko, A. (2014, November 12). Tingkat Perceraian Indonesia Meningkat Setiap Tahun, ini Datanya. Retrieved from Republika: http://www.republika.co.id/berita/nasional/umum/14/01/17/nf0ij7tingkat-perceraian-indonesia-meningkat-setiap-tahun-ini-datanya.

Stinnett, N. (1979). In Search of Strong Families. In N. B. Stinnett, Building Family Strengths. Lincoln: University of Nebraska Press.

Stinnett, N. a. (1977). Relationship Characteristics of Strong Families : Family Perspective. LincoLn: University of Nebraska Press.

Stutzman, S. E. (2011). Premarital counseling and culture: A narrative inquiry of couples' insights. Iowa: Iowa State University.

Toussaint, L. \&. (2005). Theoretical and empirical connections between forgiveness,. In E. Worthington, Handbook of forgiveness (pp. 349-362). New York: Routledge.

Zimmerman, C. C. (1960). Successful American Families. New York: Pagean Press. 